\title{
The pale mountain - a UNESCO World Heritage Site
}

\author{
Flavio V. Ruffini
}

Keywords: Dolomites, nomination, UNESCO World Heritage Site

\section{Abstract}

For the past three years, the Dolomites, the Pale Mountains, have featured on the renowned list of areas holding the title of World Natural Heritage Sites. At its $33^{\text {rd }}$ session in Seville, on 26 June 2009, the UNESCO World Heritage Committee adopted the decision to include the home of Dòna Dindia, Ey de Net, Dolasilla and King Laurin in the World Heritage List. However, the path leading to World Heritage Status had been a long one.
Profile

Protected area

Dolomites - UNESCO

World Heritage Site

Mountain range

Alps

Country

Italy

\section{The background}

The first initiatives to have the Dolomites recognized as a World Natural Heritage Site go back to the early 1990s. From 6 to 8 August 1993, during an awareness-raising campaign, the nature protection organizations Mountain Wilderness, Legambiente and SOS Dolomites collected 12000 signatures for a petition recommending UNESCO's recognition of the Dolomites as a World Natural Heritage Site.

At first, the environmental organizations' initiative met with only moderate success. At the time, the Province of Bolzano argued against this initiative, stating that the opinion of the local communities living in the Dolomites should be sought prior to any official application for World Heritage Status: that was a precondition for South Tyrol. However, activities in the 1990s served as an initial spark to fuel discussion on the issue.

\section{The candidacy}

A first attempt to propose the Dolomites as candidate World Heritage Site was made in 1997: based on a proposal by the responsible ministry in Rome, the provinces of Belluno, Bolzano and Trento began to work on the project. A consultation survey was conducted in South Tyrol in all of the 22 municipalities concerned. The results showed that 20 municipalities were in favour of the candidacy, one (Kastelruth / Castelrotto) was in favour, albeit with reservations, while another (Wolkenstein / Selva di Val Gardena) rejected the idea of an application. Also, this project came to a halt relatively quickly because the opinions of the three participating provinces on boundary delimitation were too far apart.

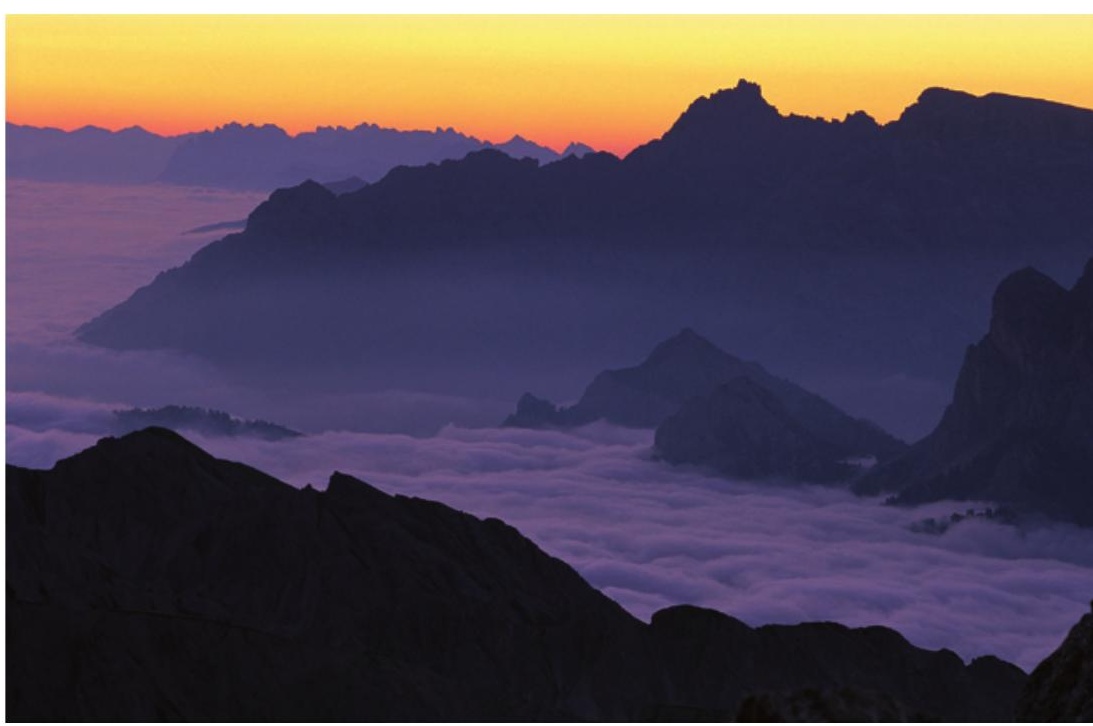

The Dolomites in a sea of clouds. (C) Sepp Hackhofer

In 2004, a second attempt was made. This time Italy's Ministry of Culture and Environment set a clear direction to follow. As required by the UNESCO for candidate World Natural Heritage Sites, only already protected areas were selected. In addition, the area under consideration was extended to the provinces of Udine and Pordenone. In September 2005, the first formal application was submitted to the World Heritage Secretariat in Paris. The proposed area included 22 protected areas.

After the list of the selected areas was published, organizations for nature and homeland conservation expressed their disagreement, particularly in South Tyrol, because some of the most representative mountain ranges, such as the Sella, Langkofel / Sassolungo, Plattkofel / Sassopiatto, Latemar and large parts of the Rosengarten / Catinaccio were not included in the ap- 


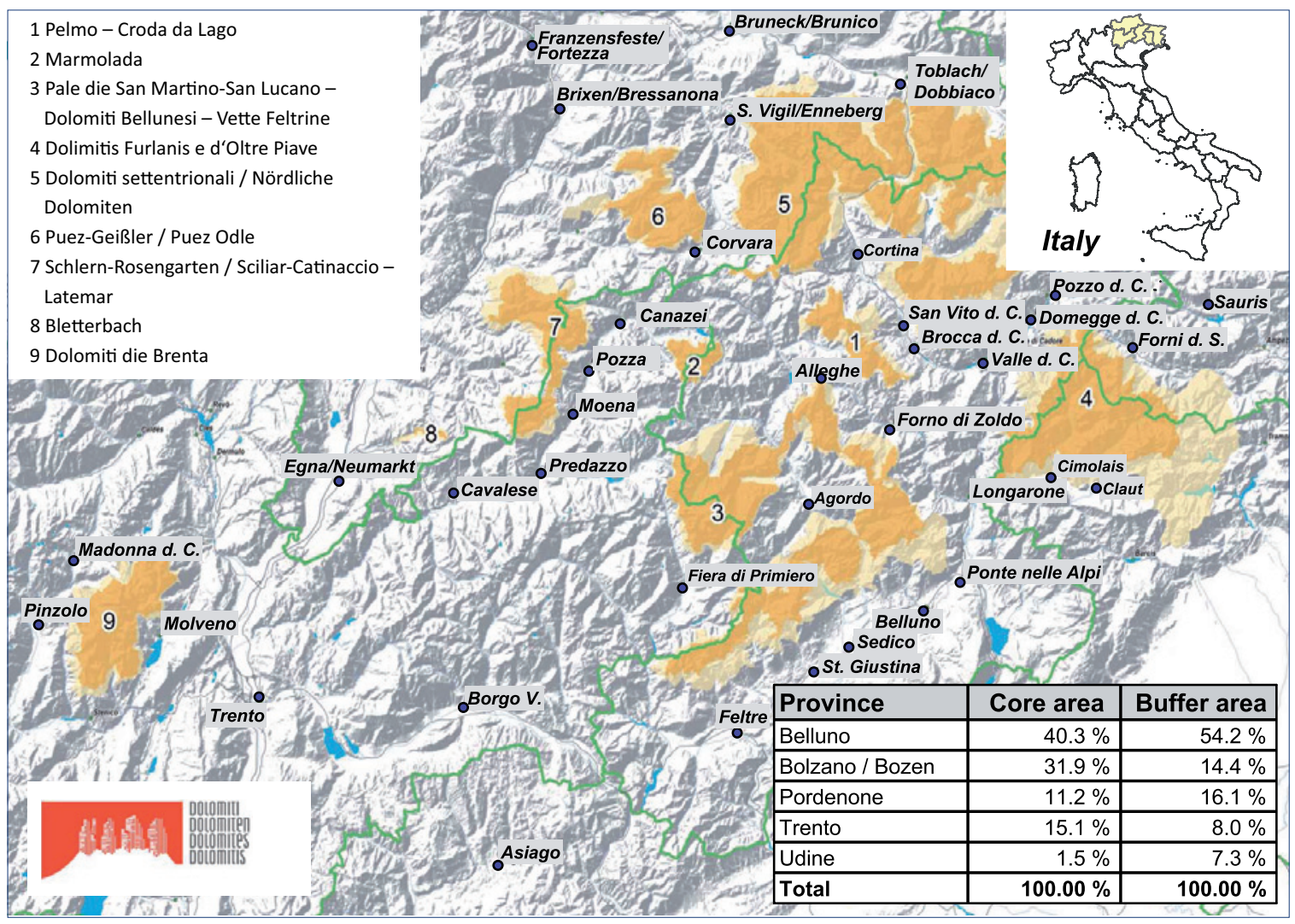

Figure 1 - The UNESCO Dolomites Natural World Heritage Site with its nine components located in the provinces of Bolzano, Trento, Belluno, Pordenone and Udine. - municipalities, — federal state border, $\square$ core area, $\square$ buffer zone.

plication. At that time, said areas were not protected and some of them are still not protected to date.

In the summer of 2007, the World Heritage Committee postponed its decision to include the Dolomites in the World Heritage List. The applicant was invited to refocus the application around the aesthetic, geological and geomorphological values of the Dolomites while selecting a smaller number of representative sub-regions.

In February 2008, the revised application was submitted to the World Heritage Secretariat. However, some essential documents were missing, namely those concerning the joint management and development arrangements, the different protection categories in the various regions, the involvement of administrations and interest groups as well as operational measures. As a result, the application was returned for review once again.

In February 2009 a revised proposal was sent to UNESCO, this time successfully. On 26 June 2009, UNESCO's World Heritage Committee unanimously declared the Dolomites a World Heritage Site: that is the world's highest recognition for a natural site. The Committee also made recommendations concerning the governance of the territory.

\section{The UNESCO area}

The Dolomites are inscribed in the World Heritage List as a serial property, i.e. one that comprises different component parts in two or more non-contiguous areas. Such a site can include a series of cultural and/or natural properties situated in different geographical locations, which are related because they belong to:

the same historical-cultural group, or

the same type of property which is characteristic of the geographical zone, or

the same geological and geomorphological formation, the same biogeographic area or the same eco-

system type (UNESCO 2011, Art.137-139).

Serial properties can be designated as national (e.g. the Dolomites) or transnational (e.g. prehistoric pile dwellings around the Alps) and are made up of component parts called systems. The UNESCO Dolomites Natural World Heritage Site includes nine such systems located in the provinces of Bolzano, Trento, Belluno, Pordenone and Udine (Figure 1). The decision to nominate the Dolomites as a serial property was justified by the desire to have all of the most significant natural resources of this mountain range feature together, as a whole, on the World Heritage List.

The largest share of the world heritage area belongs to the provinces of Belluno (core area: $40.3 \%$ ) and Bolzano (core area: 31.9\%). Existing legal protection extends to $99.8 \%$ of the nominated property, and to $98 \%$ of the area included in buffer zones of the Dolomites World Heritage area. One component part of the nominated property is largely within a national park and most of the others are protected as provin- 


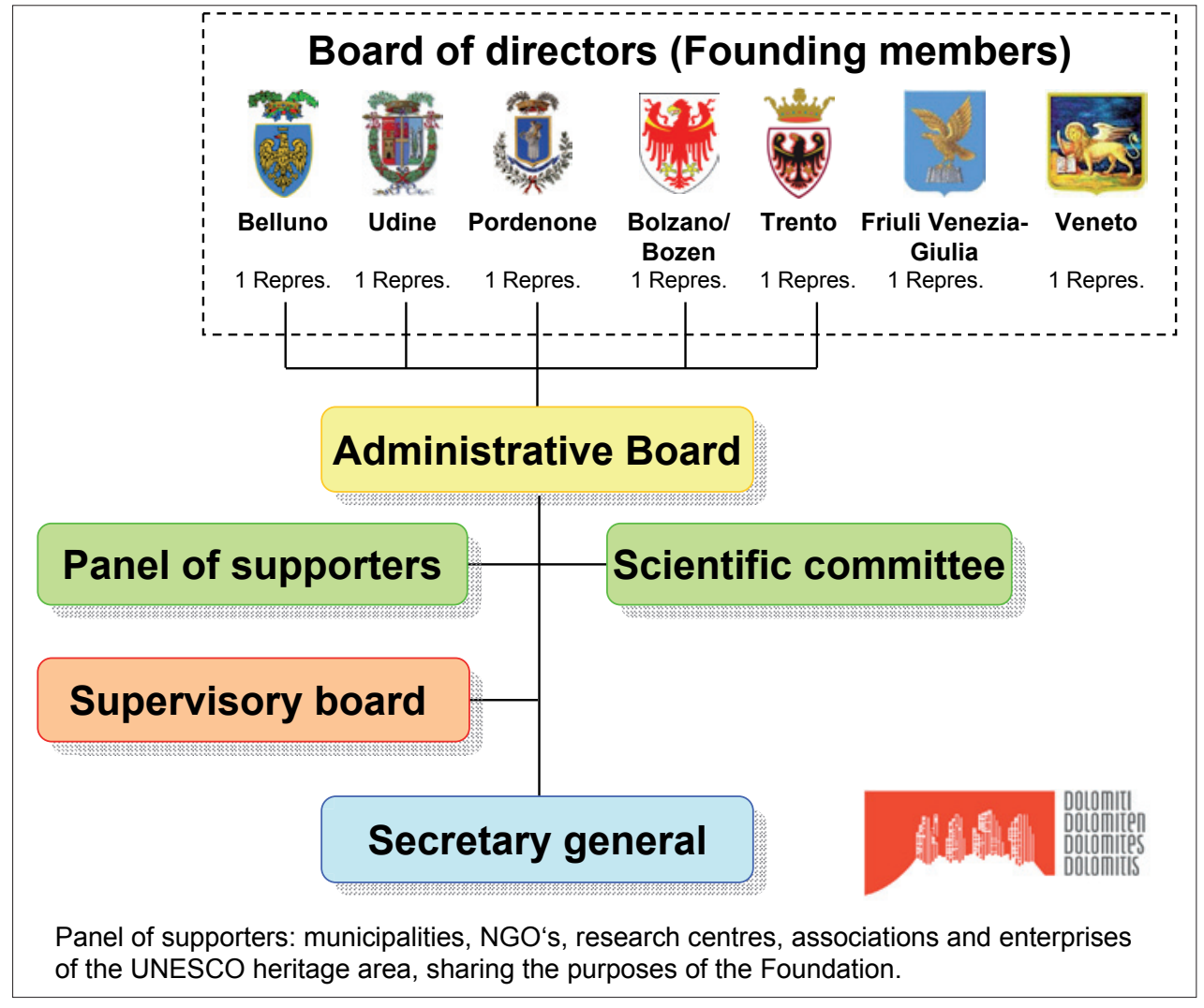

Figure 2 - The Foundation Dolomiti - Dolomiten - Dolomites - Dolomitis UNESCO was set up in 2010.

cial nature parks. Overall, $71 \%$ of the nominated area is protected within a national park or provincial nature parks; $94 \%$ and $83 \%$ are protected as Sites of Community Importance) or Specially Protected Zones, respectively, within the EU Natura 2000 network under its Habitats (92/43/EEC) and Birds (79/409/EEC) Directives; and $86 \%$ are protected by Article 142 of Italy's national Code of Cultural Heritage and Landscape, as last modified in March 2008, which states that, inter alia, areas at altitudes above $1600 \mathrm{~m}$ enjoy special protection (so called Galasso law). The Bletterbach canyon component is protected as a natural monument.

Very small unprotected areas remain within the buffer zones as a result of efforts to link the component parts of the serial property and/or streamline boundaries, and the inclusion of these areas in the nomination was deemed acceptable by the UNESCO Committee (IUCN 2009).

\section{Reasons for the nomination}

The basic definition of world heritage is contained in the World Heritage Convention of 1972, which refers to "parts of the cultural or natural heritage [that] are of outstanding interest and therefore need to be preserved as part of the world heritage of mankind as a whole." (Preamble to the World Heritage Convention, UNESCO 1972). The decisive factor is their outstanding universal value for historical, artistic or scientific reasons. According to the World Heritage Convention, these assets do not belong solely to the state on whose territory they are located. Rather, they ideally belong to all mankind (Schlünkes 2009).

In order for a cultural or natural property to be included on the World Heritage List, it must meet the overarching criteria of uniqueness, authenticity (historical authenticity) and integrity (intactness). These characteristics have been specified by UNESCO on the basis of ten criteria. The first six criteria are particularly relevant for cultural sites and cultural landscapes while the last four apply to natural landscapes. Criteria (vii) and (viii) were especially pertinent for the Dolomites:

- Criterion (vii): Superlative natural phenomena or natural beauty and aesthetic importance

- Criterion (viii): Earth's history, geological and geomorphic features and processes

The UNESCO Committee based its decision on the unique monumental beauty of the area and the unique geology of the Dolomites and considered criterion (vii) to be fully met for the following reasons:

"The Dolomites are widely regarded as being among the most attractive mountain landscapes in the world. Their intrinsic beauty derives from a variety of spectacular vertical forms such as pinnacles, spires and towers, with contrasting horizontal surfaces including ledges, crags and plateaux, all of which rise abruptly above extensive talus deposits and more gentle foothills. A great diversity of colours is provided by the contrasts between the bare pale-coloured rock surfaces and the forests and meadows 
Table 1 - Overview of the individual systems of the Dolomites World Heritage Site area (IUCN 2009).

\begin{tabular}{|c|c|c|c|}
\hline Component part & Core area [ha] & Buffer area [ha] & Total [ha] \\
\hline Component part 1: Pelmo Croda di Lago & 4344 & 2437 & 6771 \\
\hline \multicolumn{4}{|c|}{$\begin{array}{l}\text { Dramatic landscape with wide range of landforms including towers, plateaux, ledges and landslides, and evidence of last glacial maxi- } \\
\text { mum. } \\
\text { - Late Permian to early Jurassic succession, presenting rock and fossil records, tectonic and sedimentological across an interval of c. } 100 \\
\text { million years. }\end{array}$} \\
\hline Component part 2: Marmolada & 4344 & 2437 & 6771 \\
\hline \multicolumn{4}{|c|}{$\begin{array}{l}\text { - Includes the highest summit of the Dolomites }(3343 \mathrm{~m}) \text {, known as Queen of the Dolomites, a rocky massif with high relief and vertical } \\
\text { walls. } \\
\text { - Geological record of Triassic sedimentary platform and overlying volcanic sediments. }\end{array}$} \\
\hline $\begin{array}{l}\text { Component part 3: Pale di San martino, San Lucano, } \\
\text { Dolomiti Bellunesi, Vette Feltrine }\end{array}$ & 31666 & 23669 & 55335 \\
\hline \multicolumn{4}{|c|}{$\begin{array}{l}\text { - Horseshoe-shaped component with typical dolomite landscapes including cliffs, plateaux, valleys, pinnacles and walls. } \\
\text { - One of the most complete stratigraphic series of the Dolomites from early Palaeozoic to the Cretaceous. }\end{array}$} \\
\hline Component part 4: Dolomiti Friulane e d'Oltre Piave & 21461 & 25028 & 46489 \\
\hline \multicolumn{4}{|c|}{$\begin{array}{l}\text { - Many sheer rock walls, pinnacles, towers and valleys. } \\
\text { - Stratigraphic succession dominated by dolomitic-calcareous rocks with repeated stratigraphy due to faulting. }\end{array}$} \\
\hline Component part 5: Dolomiti settentrionali & 53586 & 25181 & 78767 \\
\hline \multicolumn{4}{|c|}{$\begin{array}{l}\text { Extensive areas of mountainous topography. Three main mountain groups, with significant plateaux in the northwestern part and rocky } \\
\text { cliffs further south. } \\
\text { - The most complete stratigraphic sequence of the Dolomites, with three dimensional exposures of carbonate platforms. Fossil records of } \\
\text { international significance documenting recovery of life after the Permian-Triassic extinction and including important reef and plant fossil } \\
\text { remains. }\end{array}$} \\
\hline Component part 6: Puez Geißler & 7930 & 2866 & 10796 \\
\hline \multicolumn{4}{|c|}{$\begin{array}{l}\text { Two large dolomite plateaux isolated by sheer escarpment ridges, with some of the highest peaks of the Dolomites and displaying a typi- } \\
\text { cal dolomite landscape. } \\
\text { - Well preserved stratigraphic succession with little deformation, and internationally important stratigraphic and fossil bearing horizons. }\end{array}$} \\
\hline Component part 7: Schlern-Rosengarten-Latemar & 9308 & 4771 & 14073 \\
\hline \multicolumn{4}{|c|}{$\begin{array}{l}\text { Wide variety of landforms with sheer dolomite peaks and high relief. } \\
\text { - Key Triassic stratigraphic and palaeontological localities, including the Latemar Reef exposure of an isolated carbonate platform, subject } \\
\text { of many international studies. }\end{array}$} \\
\hline Component part 8: Bletterbach canyon & 271 & 547 & 818 \\
\hline \multicolumn{4}{|c|}{$\begin{array}{l}\text { Deep and meandering gorge, creating the important exposure of geology that is the key value of this component. } \\
\text { Well exposed succession of Permian-Triassic rocks, particularly important for documenting Permian palaeo-environments and trace fossil } \\
\text { remains of vertebrate life at that time. }\end{array}$} \\
\hline Component part 9: Dolomiti di Brenta & 11135 & 4201 & 1336 \\
\hline \multicolumn{4}{|c|}{$\begin{array}{l}\text { Spectacular structural and climatic landforms including rock towers, steeples, ledges, cirques, landslides and a well developed karst } \\
\text { system. } \\
\text { Extensive exposures document the structural and stratigraphic evolution of the South Alpine passive margin and tectonic history of the } \\
\text { Dolomites. }\end{array}$} \\
\hline Dolomites World Heritage, total area & 141903 & 89266 & 231169 \\
\hline
\end{tabular}

below. The mountains rise as peaks with intervening ravines (...). Some of the rock cliffs here rise more than $1500 \mathrm{~m}$ and are among the highest limestone walls found anywhere in the world. The distinctive scenery of the Dolomites has become the archetype of a dolomitic landscape."

Criterion (viii) was justified as follows:

"The Dolomites are of international significance for geomorphology, as the classic site for the development of mountains in dolomitic limestone. The area presents a wide range of landforms related to erosion, tectonism and glaciation. The quantity and concentration of extremely varied limestone formations is extraordinary in a global context, including peaks, towers, pinnacles and some of the highest vertical rock walls in the world. The geological values are also of international significance, notably the evidence of Mesozoic carbonate platforms, or 'fossilized atolls', particularly in terms of the evidence they provide of the evolution of the bio-constructors after the Permian / Triassic boundary, and the preservation of the relationships between the reefs they constructed and their surrounding basins. The Dolo- mites also include several internationally important type sections for the stratigraphy of the Triassic Period. The scientific values of the property are also supported by the evidence of a long history of study and recognition at the international level. Taken together, the combination of geomorphological and geological values creates a property of global significance."

Individual areas undoubtedly fulfil these overriding principles (Table 1).

The designation as a serial World Heritage property was made conditional upon certain requests of the Committee, to be met before the $35^{\text {th }}$ session of the World Heritage Committee in 2011 in order to address fully the requirements of the Operational Guidelines: - The anticipated inter-provincial foundation Dolomiti - Dolomiten - Dolomitis - Dolomites UNESCO should be set up;

an action-oriented overall management strategy for the whole of the serial property should be developed in consultation with relevant stakeholders; 


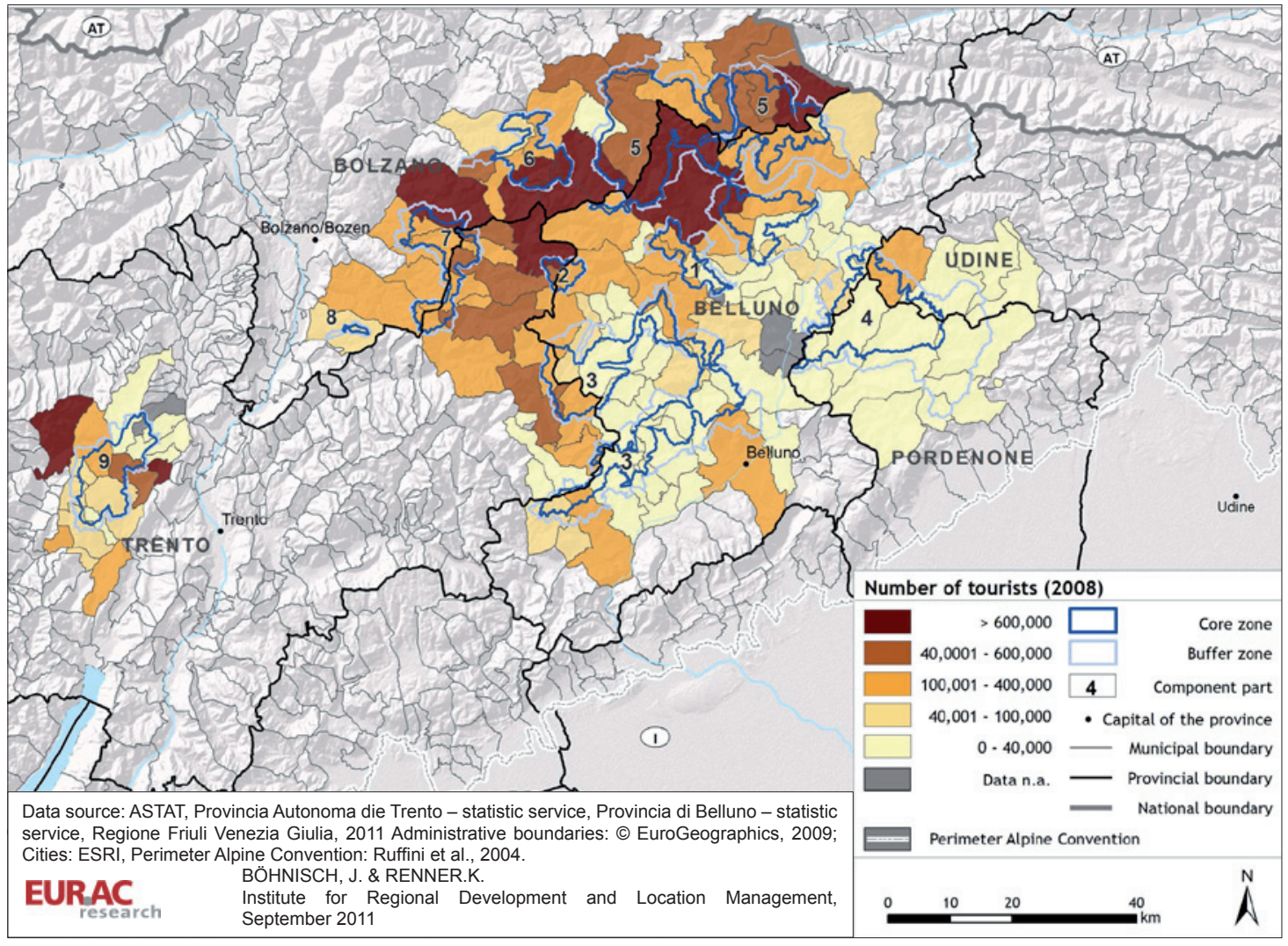

Figure 3 - Map of structural differences expressed in number of tourists.

- individual management plans for each of the component parts of the serial property should be completed to ensure delivery of the overall framework as well as the local management of conservation policies; a comprehensive strategy for sustainable tourism and visitor use should be developed covering the property, its buffer zones and considering appropriate links to the wider region.

\section{Outlook}

For the past three years, the Dolomites have been proudly carrying the World Heritage label. Nevertheless, seen from the outside, progress appears somewhat slow. That is mainly due to the different institutional competencies and responsibilities of the various regions and provinces involved. The World Heritage Site is governed jointly by autonomous provinces and provinces with an ordinary statute. Two of the latter, however, namely Udine and Pordenone, belong to an autonomous region with special statute (Friuli-Venezia-Giulia), while one province with ordinary statute (Belluno) belongs to an ordinarily constituted region (the Veneto). As a result, decision-making often occurs at different speeds. In addition, Italian provinces with ordinary statute have a rather limited budget available.

In the spring of 2010, the participating provinces and regions set up a foundation to manage the world heritage, harmonize the different approaches and define the strategic focus of cross-border issues concerning the UNESCO site management (Figure 2).
The foundation is intended as a platform to coordinate the various activities, including those concerning the cross-border protection of the World Heritage Property, communication with the outside world, training and promotion of the site.

Regional networks were set up to help address relevant aspects for the area (geology, nature parks, mobility, marketing, sustainable development and tourism) in a cross-border approach.

This approach is undoubtedly very innovative and has received much praise from UNESCO. However, its implementation requires the presence of an overall strategy and a joint vision, common rules and, especially, commonly agreed priorities. For the time being, all that is still at an embryonic stage so that we are induced to perceive the entire process as a rather uncoordinated form of broad activism.

Meanwhile, management plans have been prepared for all systems of the World Heritage Site (WHS) and a first draft strategy for tourism is also available. Considering the importance of the tourist industry, it was deemed crucial to assess both the way in which its growth can be fostered while respecting the needs of the World Heritage Property and how the region can benefit from this asset. The survey showed major structural differences within the WHS: while some areas in this region boast a very strong tourist industry, other valleys face migration and depression (Figure 3). The challenge here will be to define bold strategic guidelines that will encourage each area to take on responsibilities according to its actual situation. 


\section{References}

Fondazione UNESCO Dolomiti-Dolomiten-Dolomites-Dolomitis 2012 (ed.). Turismo sostenibile nelle dolomiti: una strategia per il bene patrimonio dell'umanità UNESCO. Elaborated by: EURAC-Research, Institute for Regional Develpoment and Location Management. Cortina d'Ampezzo. Unpublished manuscript.

IUCN 2009. IUCN Evaluation of Nominations of Natural and Mixed Properties to the World Heritage List. IUCN Report, April 2009 for the World Heritage Committee, $33^{\text {rd }}$ Session, Sevilla, Spain, June 2009.

Schlünkes, K. 2009. Das UNESCO-Welterbe. In: Welterbe-Manual. Handbuch zur Umsetzung der Welterbekonvention in Deutschland, Luxemburg, Österreich und der Schweiz. Deutsche UNESCO-Kommission.

UNESCO 1972. Convention concerning the protection of the world cultural a natural heritage. Adopted by the General conference at its seventeenth session. Paris, 16 November 1972.

UNESCO 2011. Operational Guidelines for the Implementation of the World Heritage Convention. Paris.

\section{Author}

\section{Flavio V. Ruffini}

is the current Head of the Department for Spatial Planning, Environment and Energy, the administration in charge of the management of the UNESCO site components located in the Autonomous Province of Bolzano; previously Head of the Institute for Regional Development of the European Academy Bolzano until 2009; author of numerous publications.

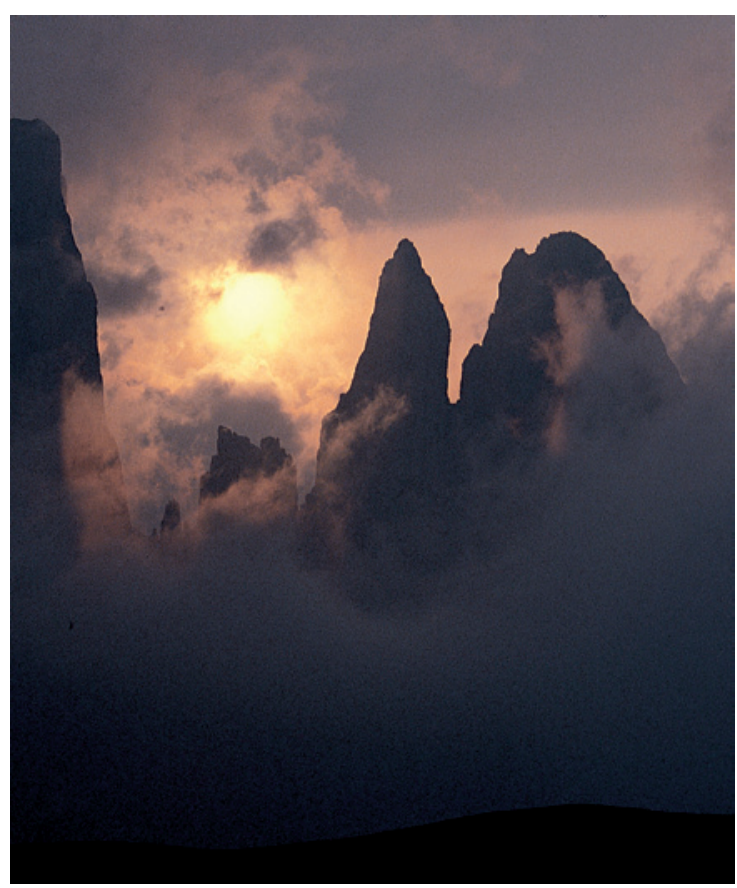

The peaks of Euringer and Santner Spitzen, Schlern-Rosengarten Nature Park. C Renato Sascor 